\title{
Macrofauna on flood delta shoals in the Wadden Sea with an underground association between the lugworm Arenicola marina and the amphipod Urothoe poseidonis
}

\author{
D. Lackschewitz \& K. Reise
}

\author{
Biologische Anstalt Helgoland, Wattenmeerstation Sylt; D-25992 List, Germany
}

\begin{abstract}
Living conditions for macrofauna on flood delta shoals are determined by surf, strong currents and sediment mobility. Thus, a unique assemblage of invertebrate species colonize these far off-shore, low intertidal flats. We here describe the macrobenthic fauna of emerging shoals in the Wadden Sea between the islands of Römö and Sylt. Besides ubiquitous macroinvertebrates of the intertidal zone and species which attain their main distribution in the subtidal zone, the flood delta shoals are characterized by organisms adapted to live in these highly unstable sediments, like the polychaetes Spio martinensis, Streptosyllis websteri, Magelona mirabilis, Psammodrilus balanoglossoides, the pericarid crustaceans Cumopsis goodsiri, Tanaissus lilljeborgi, Bathyporeia sarsi and a few others. Average abundance $\left(1440 \mathrm{~m}^{-2}\right.$ of ind $\left.>1 \mathrm{~mm}\right)$ and biomass $\left(12.9 \mathrm{~g} \mathrm{AFDW} \mathrm{m}^{-2}\right)$ were low compared to other intertidal habitats in the Wadden Sea. Biomass was dominated by largesized individuals of the lugworm Arenicola marina. The U-shaped burrows of these polychaetes

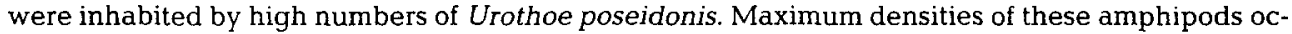
curred in the deepest parts of the burrows. Sampling at approximately monthly intervals revealed no apparent seasonality of $U$. poseidonis abundance. Together with small Capitella capitata, these amphipods constitute a deep-dwelling component of the macrofauna associated with lugworms, which is separated from all other macrofauna living at the sediment surface. As a response to rising sea level and increasing tidal ranges, we expect the unstable sandy shoals, inhabited by numerous Spio martinensis and Urothoe poseidonis, to expand within the Wadden Sea at the cost of stable sandy flats with abundant macrofauna.
\end{abstract}

\section{INTRODUCTION}

For the coastal waters of the eastern North Sea, an elevated level of macrozoobenthic biomass (Beukema 1991; Beukema \& Cadée, 1986) has been interpreted as a response to increasing nutrient concentrations and to a change in phytoplankton composition over the last decades (Cadée, 1992; Hickel et al., 1995). On the other hand, rising sea level and amplification of the tidal range in the Wadden Sea (Jensen et al., 1992) have focused attention on a possible future reduction of tidal flat areas (Misdorp et al., 1990). An increase in hydrodynamic forces is likely to expand unstable rippled sand flats at the expense of stable, sedimentary areas, thus changing intertidal morphology and habitat composition.

The tidal waters, passing through the inlets between the barrier islands of the Wadden Sea, generate strong currents. These carve out deep channels and form arcs of sandy 
shoals, emerging during ebb tides, in the ebb and flood deltas of the tidal inlets (Ehlers, 1988). While the former are exposed to the surf of the North Sea, flood delta shoals are sheltered by the barrier islands and stretch out along deep tidal channels. Some of them rise to form higher tidal flats with more stable sediment.

Within the framework of the ecosystem research project SWAP (Gätje \& Reise, 1998), a survey of the intertidal macrobenthos was conducted. As a part of this study, we investigated the macrofauna of emerging flood delta shoals in the northern Wadden Sea, east of the barrier islands of Römö and Sylt. In particular the association of lugworms (Arenicola marina) and amphipods (Urothoe poseidonis) was studied in detail.

Since hydrodynamic forces and sediment mobility affect the composition and distribution pattern of macrozoobenthos (Dörjes, 1976; Dexter, 1984; Zühlke \& Reise, 1994), we here suggest that the macrofauna assemblage of the emerging flood delta shoals may be used as an indicator for the effects of increasing energy input and sediment mobility in the Wadden Sea.

\section{MATERIAL AND METHODS}

The Sylt-Römö Wadden Sea is located in the southeastern part of the North Sea at the Danish-German borderline. It is enclosed by the islands of Sylt and Römö, and by two causeways connecting the islands to the mainland (Fig. 1). The bay comprises approximately $400 \mathrm{~km}^{2}$ of which about $150 \mathrm{~km}^{2}$ consist of intertidal flats (Gätje \& Reise, 1998). Tides are semi-diurnal with an average amplitude of $1.8 \mathrm{~m}$. Salinity remains close to 30 psu. Within the Sylt-Römö bay the tidal inlet tri-furcates, transporting roughly $7 \times 10^{8} \mathrm{~m}^{3}$ of water to and fro with the tides. In close vicinity to the deep tidal channels, flood delta shoals are subject to strong tidal currents. These shoals are composed of clean rippled sand and emerge for up to $2 \mathrm{~h}$ during normal ebb-tide. Maximum current velocities of $70 \mathrm{~cm} \mathrm{~s}^{-1}$ (Walter, pers. comm.) rework the sediment down to 2 to $8 \mathrm{~cm}$ below surface (Bayerl, 1992). Most shoals investigated consist of fine grained sand with modal diameters of less than $0.25 \mathrm{~mm}(2.2-2.9 \mathrm{PHI}$; Wentworth scale). Only at study site 2 does the incoming surf from the North Sea cause a somewhat coarser sediment (modal value of $0.28 \mathrm{~mm} ; 1.9 \mathrm{PHI})$. The mean percentage of silt and clay $(<0.063 \mathrm{~mm})$ on the shoals is low (on average $2.3 \%$ ). The majority of the shoals cover far offshore flats, separated from the islands and the mainland by tidal gullies. For sampling, we operationally defined emerging shoals as rippled, sandy flats within a distance of $<500 \mathrm{~m}$ off the $-5 \mathrm{~m}$ depth contour of the nearest tidal channel (Fig. 1).

At each of six sites three replicate cores of $200 \mathrm{~cm}^{2}$ and $20 \mathrm{~cm}$ depth were taken, $100 \mathrm{~m}$ apart from each other. The sediment was sieved in the field through $1 \mathrm{~mm}$ mesh size, and the residue was taken to the lab for analysis. An additional set of nine cores of $10 \mathrm{~cm}^{2}$ and $5 \mathrm{~cm}$ depth was sieved through a $0.5 \mathrm{~mm}$ mesh for small macrofauna and juvenile stages. The abundance of the deep-dwelling lugworm Arenicola marina was estimated by counting the fecal casts on 30 plots of $1 \mathrm{~m}^{2}$ at each site. All regular sampling was conducted during summer (June to September) in 1992 and 1993. Throughout the text, standard deviations are given in brackets following the mean value.

In the laboratory all animals were sorted alive, counted and identified to species level. Mean abundances were calculated from the replicates for each site. When small species were present in both types of core samples, abundances were calculated from the individuals found in the small cores. Biomass was determined for each site from the com- 


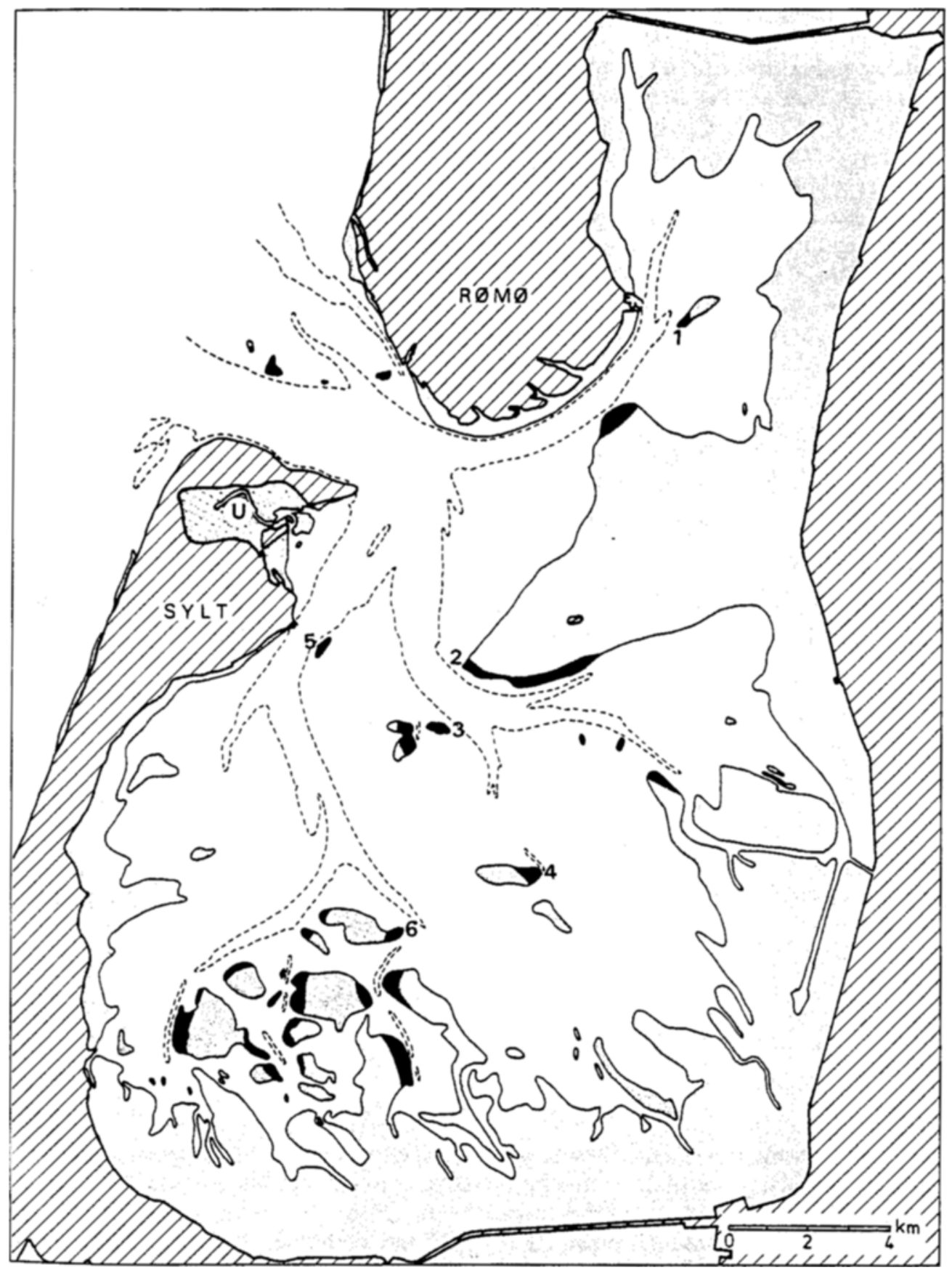

Fig. 1. The Wadden Sea between the islands of Sylt and Römö. White: subtidal (below mean spring low tide level); broken line: $-5 \mathrm{~m}$ depth contour delimiting major channels; shaded: intertidal flats with emerging shoals (dark shading), except for locations where flats steeply merge into island shore face; hatched: islands and mainland. Numbers refer to sampling sites, ' $U$ ' marks sampling location for Urothoe poseidonis 
bined sample size of $600 \mathrm{~cm}^{2}$. Separated according to species or groups of similar species, organisms were dried at $80^{\circ} \mathrm{C}$ for 3 to 5 days and weighed. After being burnt in a furnace at $520^{\circ} \mathrm{C}$ for $12 \mathrm{~h}$, they were weighed again. The weight loss is considered to represent the ash-free dry weight (AFDW) and is used as a measure of biomass. For molluscs, 15 to $30 \%$ of the AFDW turned out to result from the combustion of the shells, varying between species and size classes. Conversion factors were estimated by burning the soft parts and shells separately. Biomass of Arenicola marina was calculated by multiplying mean counts of fecal casts with average individual weights, determined from 20 individuals collected at site 1 and 6 .

To study the vertical distribution of Urothoe poseidonis, supplementary surveys were conducted. At site 6,13 replicate cores of $20 \mathrm{~cm}^{2}$ and about $30 \mathrm{~cm}$ in depth were taken at head and tail shafts of lugworm burrows as well as $50 \mathrm{~cm}$ apart from the nearest burrow structure. The sediment was sieved in the field through $1 \mathrm{~mm}$ mesh size. To include the deeper parts of the burrows in our sampling, we took another set of 6 replicate core samples of $80 \mathrm{~cm}^{2}$ and $40 \mathrm{~cm}$ in depth from head and tail shafts and from outside the burrows. We divided the cores into 4 depth intervals of $10 \mathrm{~cm}$ each and sieved the sediment through $0.5 \mathrm{~mm}$ mesh. We also excavated one of the burrows and took 11 contiguous samples of $25 \mathrm{~cm}^{2}$ from its base, sieved through $0.5 \mathrm{~mm}$.

Seasonal dynamics of Urothoe poseidonis abundances were investigated in 1994/ 1995 at study site $U$ (Fig. 1). This is the only location in the study area from which $U$. poseidonis is known apart from the emerging shoals. Core samples of $20 \mathrm{~cm}^{2}$ and about $30 \mathrm{~cm}$ in depth were sieved through $0.5 \mathrm{~mm}$ mesh size. Merely samples with 5 or more $U$. poseidonis individuals were kept, making up sets of 10 replicate core samples or 8 (June 1994), respectively. The amphipods were counted in the laboratory and their body length was measured.

According to recent taxonomic nomenclature (Hartmann-Schröder, 1996), polychaetes of the genus Spio in the area belong to three species (S. filicornis, S. martinensis and S. goniocephala). Therefore we collected 90 Spio individuals at sampling site 6 in March 1998 and identified them to the species level. Except for 2 individuals, all Spio examined turned out to be $S$. martinensis. It should be noted that the species named $S$. filicornis in former publications concerning the intertidal zone of the Wadden Sea (cf. Zühlke \& Reise, 1994) is likely to be $S$. martinensis, too.

\section{RESULTS}

\section{Macrofaunal assemblage}

The emerging shoals are characterized by relatively low values for species numbers, abundance and biomass of macrobenthic fauna. A total of 26 species was found in the combined sample size of $0.36 \mathrm{~m}^{2}$, sieved through $1 \mathrm{~mm}$. Additional 7 species were retained by $0.5 \mathrm{~mm}$ (Table 1). Polychaetes proved to be by far the most diverse group, occurring with 15 species on the shoals. Species numbers per sampling site ranged from 10 to 19 , with an average of $14.5(3.4)$. Merely 5 species were present at all six sites: the polychaetes Spio martinensis, Scoloplos armiger, Nephtys hombergi, Arenicola marina and the cumacean Cumopsis goodsiri. More than half of the species were found at one or two sites only.

Average abundance of benthic macrofauna $>1 \mathrm{~mm}$ was $1440(1025)$ ind $\mathrm{m}^{-2}$. When 
Table 1. Frequency of occurrence ( 1 to 6 sites), average abundance $\mathrm{m}^{-2}$ and biomass ( $\mathrm{g}$ AFDW m $\mathrm{m}^{-2}$ with $\mathrm{SD}=$ standard deviation) of macrozoobenthic species encountered on flood delta shoals between the islands of Sylt and Römö. Counts of fecal castings $\left(^{+}\right)$, specimen retained by a $0.5-\mathrm{mm}$ mesh (*), all others by a $1-\mathrm{mm}$ mesh

\begin{tabular}{|c|c|c|c|}
\hline Species & Frequency & Abundance & Biomass (SD) \\
\hline Arenicola marina (L.) & 6 & $4^{+}$ & $6.23(4.31)$ \\
\hline Nephtys hombergi Sav. & 6 & 61 & $0.46(0.49)$ \\
\hline Scoloplos armiger (Müll.) & 6 & 181 & $1.57(1.56)$ \\
\hline Spio martinensis Mesn. & 6 & 531 & \\
\hline Cumopsis goodsiri (v. Ben.) & 6 & $167^{\circ}$ & \\
\hline Bathyporeia sarsi Watk. & 5 & 97 & $0.05(0.05)$ \\
\hline Cerastoderma edule (L.) & 4 & 42 & $2.37(5.77)$ \\
\hline Urothoe poseidonis Reib. & 4 & 161 & $0.10(0.11)$ \\
\hline Aricidea minuta South. & 3 & 11 & \\
\hline Pygospio elegans Clap. & 3 & 125 & \\
\hline Streptosyllis websteri South. & 3 & 92 & \\
\hline Hydrobia ulvae (Penn.), juv. & 3 & $186^{\circ}$ & \\
\hline Macoma balthica L. & 3 & 8 & \\
\hline Crangon crangon (L.) & 3 & 17 & \\
\hline Capitella capitata (Fabr.) & 2 & 31 & \\
\hline Magelona mirabillis (John.) & 2 & 14 & \\
\hline Psammodrilus balanoglossoides Swedm. & 2 & $37^{\circ}$ & \\
\hline Retusa obtusa (Mont.) & 2 & 6 & \\
\hline Tellina tenuis da Costa & 2 & 6 & \\
\hline Tanaissus lilljeborgi (Stebb.) & 2 & $111^{\circ}$ & \\
\hline Malacoceros tetraceros (Schmar.), juv. & 1 & $56^{*}$ & \\
\hline Nereis diversicolor Müll. & 1 & 6 & \\
\hline Scolelepis squamata Müll., juv. & 1 & $92^{\circ}$ & \\
\hline Paranais litoralis (Müll.) & 1 & 28 & \\
\hline Ensis americanus (Binn.), juv. & 1 & 6 & \\
\hline Mya arenaria L., juv. & 1 & 6 & \\
\hline \multicolumn{4}{|c|}{ 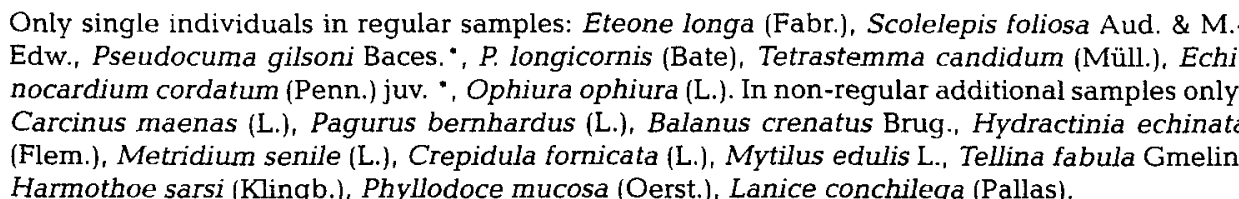 } \\
\hline
\end{tabular}

species retained only by the $0.5 \mathrm{~mm}$ mesh are included, and numbers of small organisms like Cumopsis goodsiri and juvenile Hydrobia ulvae were calculated from small samples, the total abundance increased to 2135 (1247) ind $\mathrm{m}^{-2}$. Polychaetes attained about two thirds of all individuals $>1 \mathrm{~mm}$, with Spio martinensis contributing $37 \%$. The abundance of Arenicola marina on the shoals was low (2.5 [1.9] ind $\left.\mathrm{m}^{-2}\right)$, except for site 1 (12.6 [4.3] ind $\mathrm{m}^{-2}$ ). Juvenile Hydrobia ulvae were the only molluscs of notable abundance. Small crustaceans contributed $21 \%$ of all individuals $>1 \mathrm{~mm}$. Of these, Bathyporeia sarsi, Tanaissus lilljeborgi and Cumopsis goodsini live close to the surface, while Urothoe poseidonis occurs regularly far down in the lugworm burrows, often beyond the reach of regular samples (see below). 
Average macrofauna biomass on the shoals was 12.9 (9.2) $\mathrm{g} \mathrm{AFDW} \mathrm{m}^{-2}$. When the weight loss of mollusc shells is included, biomass increased to 13.7 (10.2) $\mathrm{g} \mathrm{AFDW} \mathrm{m}^{-2}$. Only 6 species made up $95 \%$ of the benthic biomass (Table 1). Arenicola marina, although low in density, contributed almost half of the total biomass $(48 \%)$. This could be attributed to the extraordinary large size of the individuals, dwelling as deep as $50 \mathrm{~cm}$ below surface. No small or juvenile lugworms were encountered on the shoals. At site 1, where lugworm density was relatively high (12.6 [4.3] ind $\left.\mathrm{m}^{-2}\right)$, the average individual biomass was $1.2(0.6) \mathrm{g}$ AFDW $(\mathrm{n}=9)$, exceeding slightly the biomass of nearshore lugworms $(1.0[0.4] \mathrm{g}$ AFDW; $\mathrm{n}=20)$, whereas at site 6 abundance was low $\left(1.3[1.0]\right.$ ind $\left.\mathrm{m}^{-2}\right)$, but the individual biomass was as high as $2.5(0.7) \mathrm{g}$ AFDW. Average diameter of fecal strings ( $\mathrm{n}=42$; site 6 ) was $4.7(0.7) \mathrm{mm}$, while those of nearshore adult worms barely exceeded $3 \mathrm{~mm}$.

Total biomass of all polychaetes amounted to $8.7 \mathrm{~g}(67 \%)$, molluscs contributed $3.3 \mathrm{~g}$ $(25 \%)$ or, respectively, $4.0 \mathrm{~g}(29 \%)$ when shells are included, and crustaceans $0.9 \mathrm{~g}(7 \%)$. In terms of functional groups, about $8 \mathrm{~g}$ were attributed to deposit feeders and $4 \mathrm{~g}$ to suspension feeders.

\section{Distribution of Urothoe poseidonis}

The observed co-occurrence of Urothoe poseidonis and Arenicola marina may be interpreted as denoting a close association of the two species, whereby the amphipod inhabits the deeper parts of the lugworm burrows in high densities.

We investigated the distribution of $U$. poseidonis by taking core samples from head and tail shafts of lugworm burrows as well as from outside the burrows ( $n=13$ ). In head shafts an average of $12.5(9.2)$ individuals were present, whereas only two $U$. poseidonis were found in one of the replicates from tail shafts, and two others were detected in samples from outside burrow structures.

The excavation of an entire lugworm burrow yielded 173 Urothoe poseidonis, with a maximum in the anterior to middle part of the gallery (Fig. 2). With bigger core samples, reaching as deep as $40 \mathrm{~cm}(\mathrm{n}=6)$, we attempted to include more sediment from the curved part of the burrows. Again, a significant preference of $U$. poseidonis for head shaft sediment was obvious (Table 2). Also, the abundance of the polychaete Capitella capitata was higher at the basis of the head shafts. The individuals correspond to C. capitata type $S$ in Gamenick \& Giere (1994). Other species responded to the surface structures of the burrows. While maximum numbers of the amphipod Bathyporeia sarsi were found in the fecal mounds, the polychaetes Spio martinensis and juvenile Scoloplos armiger tended to be less abundant there. Vertical distribution of the infauna, as shown by $10 \mathrm{~cm}$ depth intervals, revealed for Urothoe poseidonis in the combined sample size of $480 \mathrm{~cm}^{2}$ from head shafts a vertical pattern of $0,12,92$ and 93 individuals. In tail shafts $0,6,9,0$ $U$. poseidonis were found and in sediment from outside the burrows $0,0,0,1$ individual. The respective distribution of Capitella capitata in head shafts was $0,0,14,7$ and for Cumopsis goodsiri 8, 1, 1 and 5 individuals. All other fauna was found only in the uppermost $10 \mathrm{~cm}$, except for 2 specimen of the scaleworm Harmothoe sarsi, which occurred at 20 to $30 \mathrm{~cm}$ depth in tail shafts.

Sampling at approximately monthly intervals revealed no apparent seasonality (Table 3). The average number of Urothoe poseidonis inhabiting lugworm burrow head- 


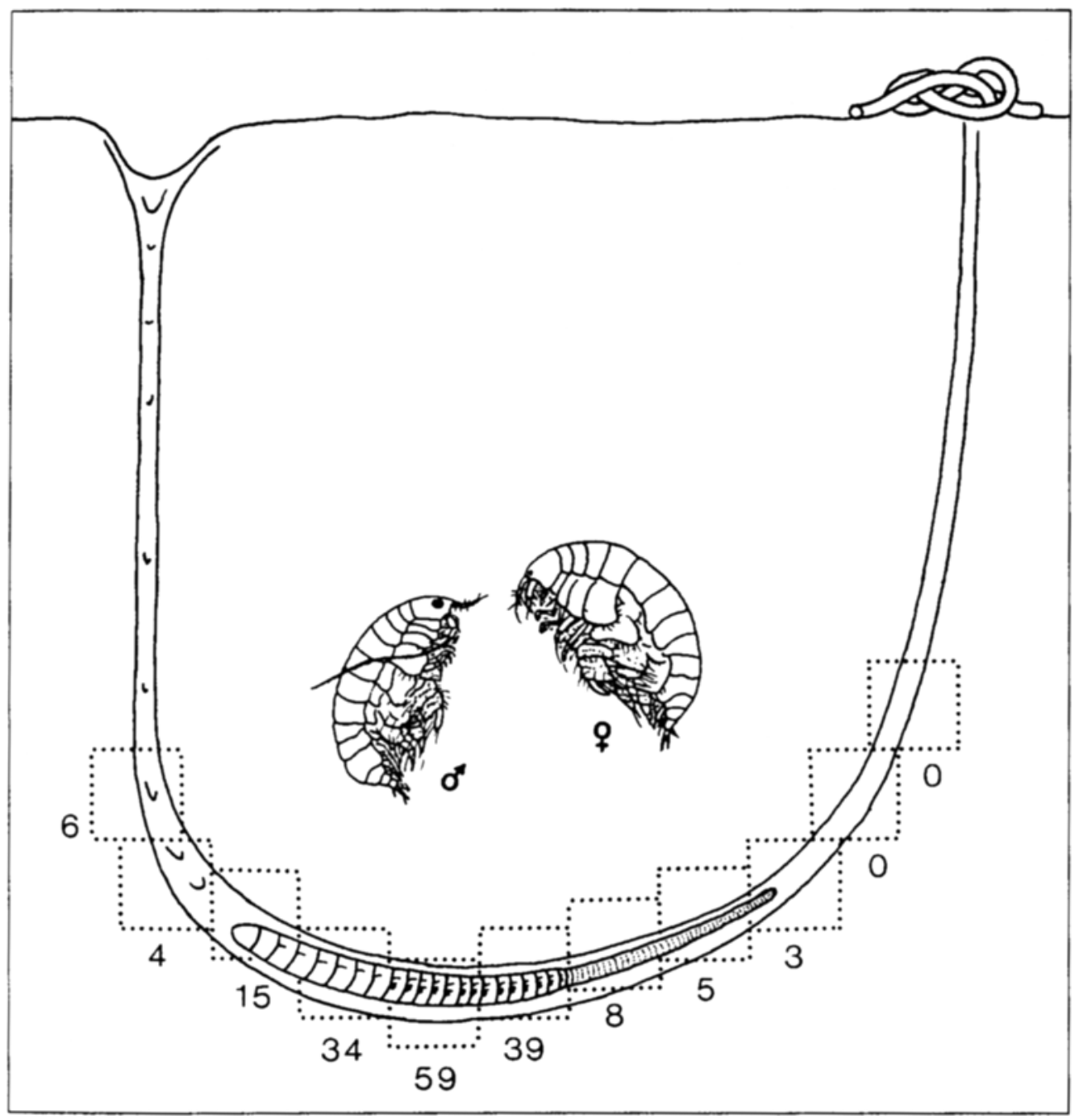

Fig. 2. Distribution of the amphipod Urothoe poseidonis (individuals in $25 \mathrm{~cm}^{3}$ ) alongside the lower part of a burrow of the lugworm Arenicola marina. The burrow is about $30 \mathrm{~cm}$ in depth and width. Sampling site 6, August 1993

shafts was 19.5 (10.5). Adult individuals reached up to $6 \mathrm{~mm}$ body length, whereas we defined individuals of $3 \mathrm{~mm}$ or less in length as juveniles. An average of $14.5 \%$ of all individuals found $(22.5 \%$ of all adults) were clearly recognizable as males with striking large dark eyes and long antennae 2. Eggbearing females had 4 to 10 relatively large eggs in their brood pouches. During our survey these were encountered only in June 1994 (9\% of all individuals found), July (1\%) and May 1995 (18\%). This may be an artefact of inadequate sampling, since juvenile stages as small as 1 to $2 \mathrm{~mm}$ occurred throughout the year. 
Table 2. Abundance of macrofauna (>0.5 mm) below $480 \mathrm{~cm}^{2}$ in vertical sediment cores $\left(6 \times 80 \mathrm{~cm}^{2}\right.$, $40 \mathrm{~cm}$ depth) taken from head and tail shafts of lugworm burrows (Arenicola marina) and sediment $50 \mathrm{~cm}$ apart from the nearest burrow (outside). Hydrobia ulvae $(<2 \mathrm{~mm}$ ) was counted in only one sample of each type. Significantly higher values are indicated by ${ }^{*} ;$ a value significantly higher only when compared to the tail shaft samples by ${ }^{+}$(U-test, $P<0.05$ )

\begin{tabular}{|lccc|}
\hline Species & Head shaft & Tail shaft & Outside \\
\hline Urothoe poseidonis & $197^{*}$ & 15 & 1 \\
Capitella capitata & $21^{*}$ & 0 & 1 \\
Cumopsis goodsiri & 15 & 4 & 9 \\
Bathyporeia sarsi & 12 & $88^{*}$ & 6 \\
Harmothoe sarsi & 0 & 2 & 0 \\
Pygospio elegans & 9 & 14 & 16 \\
Spio martinensis & $101^{+}$ & 47 & 75 \\
Scoloplos armiger & 31 & 10 & 31 \\
Streptosyllis websteri & 1 & 1 & 1 \\
Nephtys hombergi & 2 & 2 & 2 \\
Eteone longa & 1 & 0 & 1 \\
Crangon crangon & 0 & 2 & 0 \\
Cerastoderma edule & 7 & 2 & 2 \\
Macoma balthica & 2 & 0 & 0 \\
Mytilus edulis & 1 & 0 & 0 \\
Retusa obtusa & 3 & 0 & 0 \\
Hydrobia ulvae & 2238 & 1338 & 2412 \\
\hline
\end{tabular}

Table 3. Seasonal dynamics of Urothoe poseidonis abundances. Individuals per head shaft of lugworm burrows [mean (standard deviation)] as calculated from 10 replicate core samples [ 8 replicates only] of $20 \mathrm{~cm}^{2}$ and $30 \mathrm{~cm}$ depth

\begin{tabular}{|lccc|}
\hline & Juveniles & Adults & Total \\
\hline May 1994 & $24.8(9.6)$ & $21.2(10.5)$ & $46.0(17.5)$ \\
June & $12.8(15.0)$ & $8.6(5.1)$ & $21.4(17.0)$ \\
July & $3.2(2.6)$ & $7.8(4.8)$ & $11.0(6.2)$ \\
August & $10.0(6.4)$ & $14.1(4.8)$ & $24.1(9.4)$ \\
September & $4.2(7.5)$ & $7.1(3.2)$ & $11.3(10.0)$ \\
October & $2.9(3.0)$ & $8.8(5.2)$ & $11.7(7.0)$ \\
November & $8.2(12.5)$ & $14.5(11.1)$ & $22.7(18.1)$ \\
December & $4.5(6.5)$ & $11.1(5.4)$ & $15.6(8.4)$ \\
March 1995 & $5.0(5.7)$ & $13.2(9.8)$ & $18.2(14.6)$ \\
May & $4.4(9.4)$ & $9.0(7.8)$ & $13.4(16.9)$ \\
\hline
\end{tabular}




\section{DISCUSSION}

The emerging shoals in the flood tide deltas of the Wadden Sea have often been neglected in previous benthic surveys. They are not easily accessible and emerge for a rather short time, or often not at all when onshore winds interfere with the tide. As demonstrated in this study, the benthic macrofauna is poorly represented. Even lower abundances and biomass were found on emerging ebb delta shoals in the Wadden Sea. At Mellum Riff an abundance of 210 to 300 ind $\mathrm{m}^{-2}$ was recorded by Dörjes \& Reineck (1977), and at Hohes Riff near Borkum, Obert (1982) found 1094 ind $\mathrm{m}^{-2}(>1 \mathrm{~mm})$ and an average biomass of $2.9 \mathrm{~g} \mathrm{AFDW} \mathrm{m}^{-2}$, ranging from 0.15 to $7.6 \mathrm{~g}$. Compared to the flood delta shoals investigated in our study, these shoals are exposed to the surf of the North Sea, and therefore subject to even higher sediment disturbances. More similar to the flood delta shoals considered here, is a habitat defined by Beukema (1976) for the Dutch Wadden Sea: The zone 'farthest offshore ( $7 \mathrm{~km}$ or more)', situated at low tide level with clean sand and 'severly exposed to the wash of waves and tidal currents'. Although of identical average biomass $\left(12.9 \mathrm{~g} \mathrm{AFDW} \mathrm{m}^{-2}\right)$, the main contributor there was the cockle Cerastoderma edule $(4.3 \mathrm{~g})$ and only $2.0 \mathrm{~g}$ referred to the lugworm Arenicola marina, whereas we found $2.4 \mathrm{~g}$ and $6.2 \mathrm{~g}$ for these two species, respectively.

In a survey of the Jadebusen, an enclosed bay with strong tidal currents in the southern Wadden Sea, Michaelis (1987) delimited light sand flats on the basis of aerial photographs, comparable to the flood delta shoals. These flats comprise about $15 \%$ of the intertidal area in the Jadebusen. Their average macrobenthic abundance of 1429 ind $\mathrm{m}^{-2}$ (>1 mm) and biomass of $11.4 \mathrm{~g} \mathrm{AFDW} \mathrm{m}^{-2}$ proved to be rather similar to the respective values of the shoals we investigated.

Macrozoobenthic surveys reveal for most intertidal habitats of the Wadden Sea higher abundances, mostly in the range of 3000 to 20000 ind $\mathrm{m}^{-2}$ (cf. Beukema, 1991; Michaelis, 1987; Obert, 1982; Reise et al., 1994). Average biomasses are between 51 and $65 \mathrm{~g} \mathrm{AFDW} \mathrm{m}^{-2}$ (see Reise et al., 1994). For the subtidal, Dekker (1989) calculated an average abundance of 14680 ind $\mathrm{m}^{-2}$ (with $88 \%$ Hydrobia ulvae) and $43.7 \mathrm{~g} \mathrm{AFDW} \mathrm{m}^{-2}$ (with $66 \%$ Mytilus edulis) on the basis of a large-scale survey of macrozoobenthos in the southern Wadden Sea. Considering only the shallow subtidal from the low tide line to $-2 \mathrm{~m}$ depth, the biomass decreased to $15.3 \mathrm{~g} \mathrm{AFDW} \mathrm{m}^{-2}$, mussels excluded. This amount is rather similar to the corresponding value obtained for the emerging shoals in this study. Thus, we conclude from the above that there exists a macrobenthic assemblage of low diversity, abundance and biomass in clean sandy sediments, located close to low tide line and subject to strong hydrodynamics in the Wadden Sea.

The species occurring on emerging shoals may be assembled in three categories: (1) ubiquituous species, common in the entire tidal zone, (2) species common in the subtidal of the adjacent North Sea, and (3) species specifically adapted to live in unstable, sandy sediments. Representatives of the first category are Arenicola marina, Nephtys hombergi, Scoloplos armiger, Pygospio elegans, Cerastoderma edule, Macoma balthica and Hydrobia ulvae. Species of category 2 are rare, e.g. the bivalves Tellina tenuis and T. fabula as well as the echinoderms Echinocardium cordatum and Ophiura ophiura (syn. O. texturata). Species such as Magelona mirabilis, Spio martinensis, Pseudocuma spp. and Urothoe poseidonis fit into category 2 and 3. More specific of category 3 are Scolelepis squamata, Streptosyllis websteri, Psammodrilus balanoglossoides, Cumopsis goodsiri, Ta- 
naissus lilljeborgi and Bathyporeia sarsi. These species of category 2 and 3 are also listed for other shoals and similar sandy habitats in the Wadden Sea by Dörjes \& Reineck (1977), Hauser \& Michaelis (1975), Michaelis (1976, 1987), Linke (1939), Obert (1982), Ohde (1981) and Smidt (1951). According to these authors, Paraonis fulgens, Haustorius arenarius and Bathyporeia pilosa, may be added.

A migrant to the emerging shoals is the gastropod Hydrobia ulvae. However, only the juveniles of this species appear on the shoals, while the adults occur in high densities on the upper shore. Juvenile mudsnails are diurnal drifters in the water column from July to September in this region (Armonies, 1992), and there is some evidence that they drift offshore in summer and onshore in autumn (Reise, 1978). In July 1993, we found about 40000 juvenile Hydrobia ulvae $\mathrm{m}^{-2}$ on a shoal. Likewise, Obert (1982) reported 24463 individuals $\mathrm{m}^{-2}$ on an ebb delta shoal off Borkum. Although these tiny transit passengers may occur in vast numbers, they have little effect on the biomass.

Other possible migrants from the nearshore zone are large-sized individuals of Arenicola marina, since small or young lugworms do not occur on the shoals. Lugworm size generally increases in offshore direction (Beukema \& de Vlas, 1979). For most shoals it should be noted that these larger individuals must have migrated through deep tidal channels to get there. They weigh about three times as much as nearshore adults, and they also dig their burrows almost twice as deep. Supposedly, they are the oldest individuals of the population.

Together with their burrow inmates Urothoe poseidonis, Capitella capitata and Harmothoe sarsi, these lugworms represent a deep-dwelling component within the macrozoobenthic assemblage of the emerging shoals. In particular the numerous $U$. poseidonis make up a reasonable share of the total abundance of macrobenthic fauna. These amphipods are known to live in or near burrows of echinoderms (Vader, 1978), and have already been found in association with Arenicola marina along the Atlantic coast of France (Goulliart, 1952). In the northern Wadden Sea, we found $U$. poseidonis only in highly unstable sediment inhabited by lugworms. But they do not occur throughout the entire habitat range of the lugworm. From a single burrow we collected 173 individuals. Considering the difficulty in sampling the lower part of the burrow in a semi-fluid sediment, this is certainly an underestimate. With the average of 4 lugworms $\mathrm{m}^{-2}$ on the shoals, at least about $700 \mathrm{U}$. poseidonis are expected to occur per $\mathrm{m}^{-2}$. This suggests a multiplication of the average abundance, obtained from regular samples (161 ind $\mathrm{m}^{-2}$, Table 1$)$, by about 4.3 .

The absence of a clear seasonal effect on the dynamics of these amphipods may indicate moderate living conditions in the lugworm burrows, e.g. steady food and oxygen supply, and minor temperature fluctuations. Low numbers of comparatively large eggs are also known from other infaunal amphipods, which generally produce fewer but larger eggs than epifaunal ones (Dolah \& Bird, 1980). It may also be speculated that parental care of Urothoe poseidonis takes place to some extent as described for other endobenthic amphipods (Thiel et al., 1997). However, the occurrence of very young stages even in winter is still open to debate, since eggbearing females were found only in summer.

Although, in our investigation, $U$. poseidonis was encountered almost exclusively within lugworm burrows, male specimen, which have big dark eyes, are described to be 
pelagic at night (Vader, 1978). The exact nature of food source has still to be analysed. Microscopic checks of fecal pellets revealed them to be composed of high amounts of unidentifiable debris as well as remainders of diatoms, nematodes and copepods (own observations).

The occurrence of Urothoe poseidonis was not recorded prior to 1964 for the southern Wadden Sea between the rivers Ems and Elbe (Michaelis, 1981), while for the northern Wadden Sea this amphipod was already documented in the 1930s (Plath, 1942). Likewise, the polychaete Spio sp. was not reported earlier than 1973 for the southern Wadden Sea (Michaelis, 1981), and the 1970s in the north (see Reise, 1978). It may be speculated that the habitat of sandy shoals with its unstable sediment was less available to these species in former times. For the western Wadden Sea, Piersma \& Koolhaas (1997) describe an area where the effects of hydrodynamics together with the consequences of dredging for cockels and mussels result in a large-scale, long-term coarsening of the tidal sediment, a decline in benthic fauna, but an intermittent increase in Urothoe poseidonis abundances.

Besides Urothoe poseidonis and Spio martinensis, a suite of characteristic species is adapted to live in the mobile sediments of the emerging shoals, like the polychaetes $\mathrm{Ma}$ gelona mirabilis, Psammodrilus balanoglossoides and Streptosyllis websteri, the peracarid crustaceans Bathyporeia sarsi, Cumopsis goodsiri and a few others. Where this group of species extends its distribution in onshore direction, it may be regarded as an indication of a higher input of hydrodynamic energy into the Wadden Sea, which is to be expected when the sea level rises and tidal range increases. Potentially this may lower macrofaunal abundance and biomass, partially reversing the effects of eutrophication. Generally, we predict an increase of sandy shoals in the Wadden Sea the expense of stable sandy flats, and a concomitant spread of Urothoe poseidonis and Spio martinensis.

Acknowledgements, We thank Birgitta Wilmes, Yves Gibon and the crew of RV 'Mya', Nils Kruse and Peter Elvert, for help with the fieldwork, and Cord Bergfeld for drawing our attention to the proper species identification in the genus Spio. We also gratefully acknowledge the helpful criticism on the manuscript by Werner Armonies.

\section{LITERATURE CITED}

Armonies, W., 1992. Migratory rhythms of drifting juvenile molluscs in tidal waters of the Wadden Sea. - Mar. Ecol. Prog. Ser. 83, 197-206.

Bayerl, K.-A., 1992. Zur jahreszeitlichen Variabilität der Oberflächensedimente im Sylter Watt nördlich des Hindenburgdammes. - Ber. Forsch.-Technol. Zent. Westküste, Büsum 2, 1-134.

Beukema, J. J., 1976. Biomass and species richness of the macro-benthic animals living on the tidal flats of the Dutch Wadden Sea. - Neth. J. Sea Res. 10, 236-261.

Beukema, J. J., 1991. Changes in the composition of the bottom fauna of a tidal-flat area during a period of eutrophication. - Mar. Biol. 111, 293-301.

Beukema, J. J. \& Cadée, G. C., 1986. Zoobenthos responses to eutrophication of the Dutch Wadden Sea. - Ophelia 26, 55-64.

Beukema, J. J. \& Vlas, J. de, 1979. Population parameters of the lugworm, Arenicola marina, living on tidal flats in the Dutch Wadden Sea. - Neth. J. Sea Res. 13, 331-353.

Cadée, G. C., 1992. Trends in the Marsdiep phytoplankton. - Publ. Ser. Neth. Inst. Sea Res. 20, 143-149.

Dekker, R., 1989. The macrozoobenthos of the subtidal western Wadden Sea. I. Biomass and species richness. - Neth. J. Sea Res. 23, 57-68. 
Dexter, D. M., 1984. Temporal and spatial variability in the community structure of the fauna of four sandy beaches in south-eastern New South Wales. - Aust. J. mar. Freshwat. Res. 35, 663-672.

Dörjes, J., 1976. Primärgefüge, Bioturbation und Makrofauna als Indikatoren des Sandversatzes im Seegebiet vor Norderney (Nordsee). Zonierung und Verteilung der Makrofauna. - Senckenberg. marit. 8, 171-188.

Dörjes, J. \& Reineck, H.-E., 1977. Fauna und Fazies einer Sandplate (Mellum Bank, Nordsee). Senckenberg. marit. 9, 19-45.

Dolah, R. F. Van \& Bird, E., 1980. A comparison of reproductive patterns in epifaunal and infaunal gammaridean amphipods. - Estuar. coast. mar. Sci. 11, 593-604.

Ehlers, J., 1988. The morphodynamics of the Wadden Sea. Balkema, Rotterdam, 397 pp.

Gamenick, I. \& Giere, O., 1994. Population dynamics and ecophysiology of Capitella capitata from North Sea intertidal flats: evidence for two sibling species. - Polychaete Res. 16, 44-47.

Gätje, C. \& Reise, K., (Eds.), 1998. Ökosystem Wattenmeer - Austausch-, Transport- und Stoffumwandlungsprozesse. Springer, Berlin, $570 \mathrm{pp}$.

Goulliart, M., 1952. Observations biologiques et recherches sur le pigment respiratoire chez l'amphipode Urothoe grimaldii. - Bull. Soc. zool. Fr. 1177, 388-394.

Hartmann-Schröder, G., 1996. Polychaeta. - Tierw. Dtl. 58, 1-648 pp.

Hauser, B. \& Michaelis, H., 1975. Die Makrofauna der Watten, Strände, Riffe und Wracks um den Hohen Knechtsand in der Wesermündung. - Jber. ForschSt. Küste, Norderney 26, 85-119.

Hickel, W., Eickhoff, M. \& Spindler, H., 1995. Langzeit-Untersuchungen von Nährstoffen und Phytoplankton in der Deutschen Bucht. - Dt. hydrogr. Z. (Suppl.) 5, 197-211.

Jensen, J., Mügge, H. E. \& Schönfeld, W., 1992. Analyse der Wasserstandsentwicklung und Tidedynamik in der Deutschen Bucht. - Küste 53, 211-275.

Linke, O., 1939. Die Biota des Jadebusens. - Helgoländer wiss. Meeresunters. 1, 201-348

Michaelis, H., 1976. Die Makrofauna des nördlichen Eversandes (Wesermündung). - Jber. ForschSt. Küste, Norderney 27, 167-179.

Michaelis, H., 1981. Recent changes in the communities of the Wadden Sea. In: Environmental problems of the Waddensea-Region. Ed. by S. Tougaard \& C.H. Ovesen. Fiskeri- og Söfartsmuseet, Esbjerg, 87-95.

Michaelis, H., 1987. Bestandsaufnahme des eulitoralen Makrobenthos im Jadebusen in Verbindung mit einer Luftbild-Analyse. - Jber. ForschSt. Küste, Norderney 38, 13-97.

Misdorp, R., Steyaert, F., Hallie, F. \& Ronde, J. de, 1990. Climate change, sea level rise and morphological developments in the Dutch Wadden Sea, a marine wetland. In: Expected effects of climate change on marine coastal ecosystems. Ed. by J. J. Beukema, W. J. Wolff \& J. J. W. M. Brouns. Kluwer, Dordrecht, 123-131.

Obert, B., 1982. Die Bodenfauna der Watten und Strände um Borkum (Emsmündung). - Jber. ForschSt. Küste, Norderney 33, 139-162.

Ohde, J., 1981. Entstehung von Besiedlungsmustern der Makro-Endofauna im Wattenmeer der Elbe-Mündung. Diss., Univ. Hamburg, 445 pp.

Piersma, T. \& Koolhaas, A., 1997. Shorebirds, shellfish(eries) and sediments around Griend, western Wadden Sea, 1988-1996. - NIOZ-Rapp. 1997-7, 1-118.

Plath, M., 1942. Die biologische Bestandsaufnahme als Verfahren zur Kennzeichnung der Wattsedimente und die Kartierung der nordfriesischen Watten. - Westküste 2, 7-46.

Reise, K., 1978. Experiments on epibenthic predation in the Wadden Sea. - Helgoländer Meeresunters. 31, 55-101.

Reise, K., Herre, E. \& Sturm, M., 1994. Biomass and abundance of macrofauna in intertidal sediments of Königshafen in the northern Wadden Sea. - Helgoländer Meeresunters. 48, 201-215.

Smidt, E. L. B., 1951. Animal production in the Danish Waddensea. - Meddr Danm. Fisk. -og Havunders. 11, 1-151.

Thiel, M., Sampson, S. \& Watling, L., 1997. Extended parental care in two endobenthic amphipods. - J. nat. Hist. 31, 713-725.

Vader, W., 1978. Association between amphipods and echinoderms. - Astarte 11, 123-134.

Zühlke, R. \& Reise, K., 1994. Response of macrofauna to drifting tidal sediments. - Helgoländer Meeresunters. 48, 277-289. 